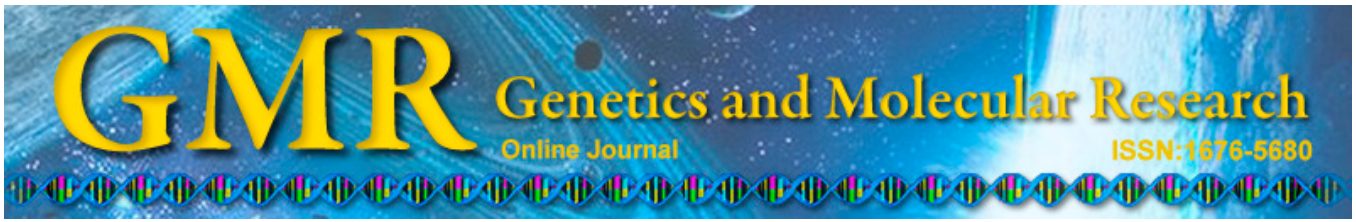

\title{
Genetic fidelity and variability of micropropagated cassava plants (Manihot esculenta Crantz) evaluated using ISSR markers
}

\author{
Á.M. Vidal ${ }^{1}$, L.J. Vieira ${ }^{2}$, C.F. Ferreira ${ }^{2}$, F.V.D. Souza ${ }^{2}$, A.S. Souza ${ }^{2}$ and \\ C.A.S. Ledo ${ }^{2}$ \\ 'Programa de Pós-Graduação em Ciências Agrárias, Centro de Ciências Agrárias, \\ Ambientais e Biológicas, Universidade Federal do Recôncavo da Bahia, \\ Cruz das Almas, BA, Brasil \\ ${ }^{2}$ Embrapa Mandioca e Fruticultura, Cruz das Almas, BA, Brasil \\ Corresponding author: Á.M. Vidal \\ E-mail: amelovidal@yahoo.com.br
}

Genet. Mol. Res. 14 (3): 7759-7770 (2015)

Received October 30, 2014

Accepted March 18, 2015

Published July 14, 2015

DOI http://dx.doi.org/10.4238/2015.July.14.2

\begin{abstract}
Molecular markers are efficient for assessing the genetic fidelity of various species of plants after in vitro culture. In this study, we evaluated the genetic fidelity and variability of micropropagated cassava plants (Manihot esculenta Crantz) using inter-simple sequence repeat markers. Twenty-two cassava accessions from the Embrapa Cassava \& Fruits Germplasm Bank were used. For each accession, DNA was extracted from a plant maintained in the field and from 3 plants grown in vitro. For DNA amplification, 27 inter-simple sequence repeat primers were used, of which 24 generated 175 bands; 100 of those bands were polymorphic and were used to study genetic variability among accessions of cassava plants maintained in the field. Based on the genetic distance matrix calculated using the arithmetic
\end{abstract}


complement of the Jaccard's index, genotypes were clustered using the unweighted pair group method using arithmetic averages. The number of bands per primer was 2-13, with an average of 7.3. For most micropropagated accessions, the fidelity study showed no genetic variation between plants of the same accessions maintained in the field and those maintained in vitro, confirming the high genetic fidelity of the micropropagated plants. However, genetic variability was observed among different accessions grown in the field, and clustering based on the dissimilarity matrix revealed 7 groups. Inter-simple sequence repeat markers were efficient for detecting the genetic homogeneity of cassava plants derived from meristem culture, demonstrating the reliability of this propagation system.

Key words: Germplasm; Meristem culture; Molecular marker; Somaclonal variation

\section{INTRODUCTION}

Cassava (Manihot esculenta Crantz) is an important food source for millions of people worldwide. In Brazil, cassava is found throughout the country, from the State of Amazonas in the north to the State of Rio Grande do Sul in the south (Fukuda et al., 2003). Cassava is one of the most important food crops in tropical and subtropical regions in the world and occupies fifth position in terms of global calory consumption, just behind wheat, rice, corn, and sorghum (Adeyemo, 2009).

Cassava is drought-tolerant and adapts well to different climate and soil conditions. The most important part of the plant is the tuberous starchy root, which is used in food and animal feed. Additionally, this plant is very important in industry and is used for starch production and the manufacture of cosmetics and pharmaceuticals, among other products (Fukuda et al., 2002; Moro, 2009).

The propagation of cassava is performed vegetatively using cuttings; low production is caused by constant multiplication in addition to infestation by diseases transmitted through successive generations (Silva et al., 2002).

Because of the slow and low propagation rate of cassava, the development of alternative techniques that allow for rapid multiplication and provision of planting materials that are free of pests and pathogens is very important. Among these alternatives, micropropagation (Souza et al., 2009) allows for the clonal production of high-quality plants in a short period of time and in reduced physical space as well as ensures phytosanitary quality (Grattapaglia and Machado, 1998).

In cassava, the establishment of in vitro cultures to initiate micropropagation begins by growing meristems, which allows for the production of healthy plantlets for forming stock plants that are able to support new plantings with high-quality propagating material. However, clonal fidelity is one of the most important prerequisites in the micropropagation of any crop species (Ribeiro, 2012).

A major limitation often encountered with in vitro culture is the presence of somaclonal variation among subclones of a parental line; somaclonal variation arises as a direct consequence of the in vitro culture of plant cells, tissues, or organs (Venkatachalam et al., 2007).

According to Alves et al. (2004), understanding the mechanisms leading to soma- 
clonal variation and the appropriate procedures for preventing its occurrence and the development of early detection methods are important factors for ensuring quality and safety in the production of micropropagated plantlets.

One strategy for detecting somaclonal variants is the use of molecular markers; these markers are part of the genome, and thus can be used to avoid environmental effects and, consequently, misidentifications (Borba et al., 2005).

Inter-simple sequence repeat (ISSR) markers have been successfully used to detect genetic differences or similarities in several micropropagated plants, including gerbera (Bhatia et al., 2009), anthurium (Gantait and Sinniah, 2011), and grape (Nookaraju and Agrawal, 2012). The high reproducibility, simplicity, and low cost of the experimental procedures of ISSR should be considered when processing a large number of samples (Goulão and Oliveira, 2001).

Therefore, the objective of this study was to evaluate the genetic diversity of accessions of cassava plants (Manihot esculenta Crantz) maintained in the field and the genetic fidelity among different accessions of micropropagated plants using ISSR markers.

\section{MATERIAL AND METHODS}

\section{Plant material and DNA extraction}

As the source of plant material, the young leaves of 22 cassava accessions from the Embrapa Cassava \& Fruits Germplasm Bank, Cruz das Almas, State of Bahia (Table 1) were used.

Table 1. Identification, common name, origin, and suitability of 22 cassava accessions maintained in the field for the assessment of in vitro genetic fidelity and diversity using ISSR markers.

\begin{tabular}{|c|c|c|c|c|}
\hline No. & Accessions & Common name & Origin & Suitability \\
\hline 1 & BGM 212 & Eucalipto & Boa Vista do Tupim-BA & Human consumption \\
\hline 2 & BGM 264 & Cigana & Amargosa-BA & Flour \\
\hline 3 & BGM 561 & Cambará & Itambé-PE & Flour \\
\hline 4 & BGM 563 & Pi90 & Muritiba-BA & Flour \\
\hline 5 & BGM $337 *$ & CM375/1 & Cali-Colômbia & - \\
\hline 6 & BGM $316^{*}$ & CM367/2 & Cali-Colômbia & - \\
\hline 7 & BGM $340 *$ & CM305/5 & Cali-Colômbia & - \\
\hline 8 & BGM 640 & Sacaí I & Paraípaba-CE & Flour \\
\hline 9 & BGM 1723 & Jussara CNPMF & Cruz das Almas-BA & Flour \\
\hline 10 & BGM 1840 & São Pedro & Belém-PA & Flour \\
\hline 11 & BGM 638 & Guarani & Pentecoste-CE & Flour \\
\hline 12 & BGM 1123 & Aipim valenca & Piritiba-BA & Human consumption \\
\hline 13 & BGM 668 & Nacionalista & Viçosa-MG & Ornamental \\
\hline 14 & BGM 1037 & Casco de burro & Aurora do Norte-TO & Human consumption \\
\hline 15 & BGM $1811 * *$ & Formosa & Cruz das Almas-BA & Flour/starch \\
\hline 16 & BGM 1245 & MNag-1 & Nigéria-África & - \\
\hline 17 & BGM 1324 & Mandioca folha virada & Afogados da Engazeira-PE & Flour \\
\hline 18 & BGM 1345 & Macaxeira preta & Congo-PB & Human consumption \\
\hline 19 & BGM 1348 & Caideira & Sumé-PB & Flour \\
\hline 20 & BGM 1371 & Mandioca alagoa & Soledade-PB & Flour \\
\hline 21 & BGM 116 & Cigana preta & Castro Alves-BA & Flour/starch \\
\hline 22 & BGM 1282 & Macaxeira-cará & Ouricuri-PE & Human consumption \\
\hline
\end{tabular}

Source: Cassava Germplasm Bank of Embrapa Cassava \& Fruits. *Fitness not informed; **Resistant to bacterial infection.

Four plants from each accession were used: 1 plant was maintained in the field (c), and 3 plants were cultured in vitro $(1 \mathrm{i}, 2 \mathrm{i}, 3 \mathrm{i})$ at the Tissue Culture Laboratory of Embrapa Cassava 
$\&$ Fruits for 7 subcultures.

DNA extraction was performed at the Molecular Biology Laboratory of Embrapa Cassava \& Fruits using the protocol as described by Doyle and Doyle (1987), with modifications. DNA in the samples was quantified on $0.8 \%$ agarose gels and visualized under ultraviolet light. The DNA was diluted to $5 \mathrm{ng} / \mu \mathrm{L}$ for amplification reactions.

\section{Amplification}

DNA amplification was performed in a thermocycler (96-Well Thermal Cycler, Applied Biosystems, Foster City, CA, USA) using 27 ISSR primers (Table 2). The final volume of the reactions was $15 \mu \mathrm{L}$ and contained $0.2 \mathrm{mM}$ dNTPs, $1 \mathrm{X}$ buffer, $2.5 \mathrm{mM} \mathrm{MgCl}, 1 \mathrm{U}$ Taq DNA polymerase, $0.4 \mathrm{mM}$ primer, and $10 \mathrm{ng}$ genomic DNA.

Table 2. List of ISSR primers used and their sequence (5'- 3').

\begin{tabular}{ll}
\hline Primer & Sequence (5'-3') \\
\hline ISSR 12 & GAGAGAGAGAGAGAGARC \\
ISSR 24 & AGTGTGTGTGTGTGGT \\
ISSR 25 & CGTGTGTGTGTGTGTG \\
ISSR 31 & CRCACCACCACCACCAC \\
ISSR $32^{*}$ & CYCACCACCACCACCAC \\
ISSR 33 & CAGCAGCAGCAGCAG \\
ISSR 34 & CAGCAGCAGCAGCAGRC \\
ISSR $35^{*}$ & CAGCAGCAGCAGCAGYC \\
ISSR 36 & CRCAGCAGCAGCAGCAG \\
ISSR 37 & CYCAGCAGCAGCAGCAG \\
ISSR 39 & GTGGTGGTGGTGGTGRC \\
ISSR 40 & GTGGTGGTGGTGGTGYC \\
ISSR 41 & CRGTGGTGGTGGTGGTG \\
ISSR 42 & CYGTGGTGGTGGTGGTG \\
ISSR 47 & CYTGTTGTTGTTGTTGT \\
ISSR 58 & ACGACGACGACGACGRC \\
ISSR 59 & AGAAGAAGAAGAAGARC \\
ISSR 69 & TTGTTGTTGTTGTTGRC \\
ISSR 83 & CTGCTGCTGCTGCTGRC \\
ISSR 86 & CGACGACGACGACGARC \\
ISSR 90 & GAAGAAGAAGAAGAARC \\
ISSR 91 & GATGATGATGATGATRC \\
ISSR 92 & GACGACGACGACGACRC \\
ISSR 93 & GAGGAGGAGGAGGAGRC \\
ISSR 94 & GTAGTAGTAGTAGTARC \\
ISSR $97 *$ & GCAGCAGCAGCAGCARC \\
ISSR 101 & GGAGGAGGAGGAGGARC \\
\hline
\end{tabular}

*Primers not used for molecular analysis because they were monomorphic.

The DNA amplification program consisted of initial denaturation at $95^{\circ} \mathrm{C}$ for $2 \mathrm{~min}$, followed by 39 cycles of denaturation at $94^{\circ} \mathrm{C}$ for $1 \mathrm{~min}$, annealing at $50^{\circ} \mathrm{C}$ for $1 \mathrm{~min}$, and extension at $72^{\circ} \mathrm{C}$ for $1 \mathrm{~min}$, with a final extension for $10 \mathrm{~min}$ at $72^{\circ} \mathrm{C}$ and hold at $14^{\circ} \mathrm{C}$. The amplified products were subjected to electrophoresis on a $2.5 \%$ agarose gel in $0.5 \mathrm{X}$ TBE buffer. The gels were stained with ethidium bromide and photographed under ultraviolet light.

\section{Data analysis}

Amplified DNA fragments were classified as having a presence or absence of bands, and a matrix was built, with 1 representing the presence and 0 representing the absence of the 
band on the gel. Genetic distances between accessions were evaluated using the dissimilarity matrix generated by the arithmetic complement of the Jaccard's index, and the clustering of genotypes was generated using the unweighted pair-group method using arithmetic averages and the Gene software (Cruz et al., 2003). A dendrogram was constructed using the STATISTICA (Statistica, 2002) software.

\section{RESULTS}

\section{Study of genetic diversity among cassava accessions maintained in the field}

Of the 27 ISSR primers tested, only 24 showed polymorphisms. These 24 primers generated a total of 175 bands, of which 100 were polymorphic (57.1\%). The number of bands from each primer ranged from 2-13, with an average of 7.3 bands per primer (Table 3 ).

\begin{tabular}{|c|c|c|c|c|}
\hline \multirow[t]{2}{*}{ Primer } & \multicolumn{4}{|c|}{ Bands } \\
\hline & Total & Monomorphic & Polymorphic & $\%$ Polymorphism \\
\hline ISSR 12 & 13 & 2 & 11 & 84.6 \\
\hline ISSR 24 & 9 & 4 & 5 & 55.6 \\
\hline ISSR 25 & 6 & 2 & 4 & 66.7 \\
\hline ISSR 31 & 7 & 5 & 2 & 28.6 \\
\hline ISSR 33 & 11 & 8 & 3 & 27.3 \\
\hline ISSR 34 & 10 & 3 & 7 & 70.0 \\
\hline ISSR 36 & 10 & 6 & 4 & 40.0 \\
\hline ISSR 37 & 4 & 3 & 1 & 25.0 \\
\hline ISSR 39 & 11 & 6 & 5 & 45.5 \\
\hline ISSR 40 & 8 & 1 & 7 & 87.5 \\
\hline ISSR 41 & 10 & 1 & 9 & 90.0 \\
\hline ISSR 42 & 9 & 4 & 5 & 55.6 \\
\hline ISSR 47 & 9 & 4 & 5 & 55.6 \\
\hline ISSR 58 & 7 & 5 & 2 & 28.6 \\
\hline ISSR 59 & 2 & 1 & 1 & 50.0 \\
\hline ISSR 69 & 7 & 3 & 4 & 57.1 \\
\hline ISSR 83 & 7 & 5 & 2 & 28.6 \\
\hline ISSR 86 & 3 & 2 & 1 & 33.3 \\
\hline ISSR 90 & 9 & 1 & 8 & 88.9 \\
\hline ISSR 91 & 6 & 1 & 5 & 83.3 \\
\hline ISSR 92 & 2 & 1 & 1 & 50.0 \\
\hline ISSR 93 & 9 & 6 & 3 & 33.3 \\
\hline ISSR 94 & 3 & 0 & 3 & 100.0 \\
\hline ISSR 101 & 3 & 1 & 2 & 66.7 \\
\hline Total & 175 & 75 & 100 & 57.1 \\
\hline Average & 7.3 & 3.1 & 4.2 & 56.3 \\
\hline
\end{tabular}

The minimum number of polymorphic bands ( 1 band) was obtained for ISSR primers $37,59,86$, and 92 . The maximum number of polymorphic bands was 11 bands and was obtained from the ISSR 12 primer, indicating $84.6 \%$ polymorphism (Table 3 ).

The electrophoretic profile of 22 accessions from the field using the ISSR 90 primer is shown in Figure 1. 


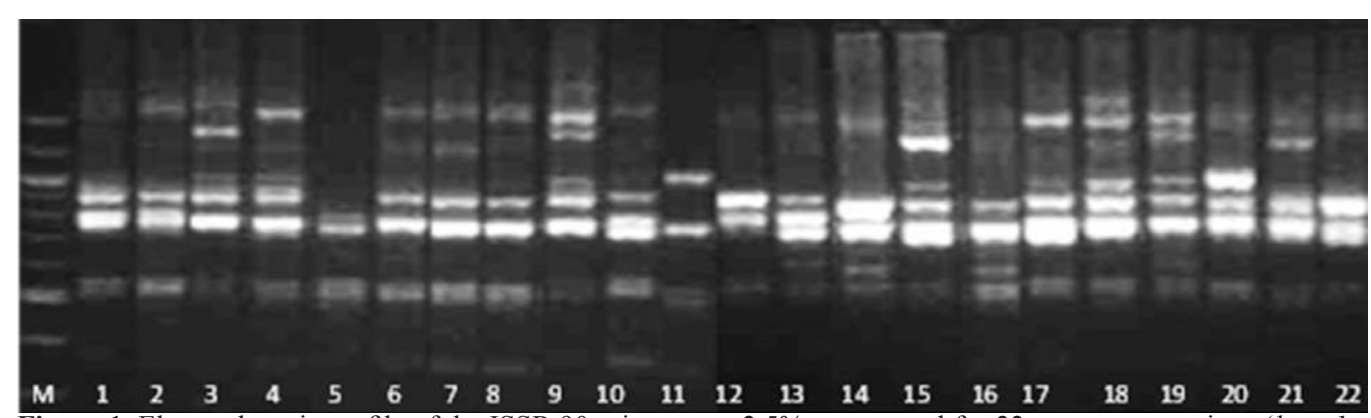

Figure 1. Electrophoretic profile of the ISSR 90 primer on a $2.5 \%$ agarose gel for 22 cassava accessions (lane 1 BGM 212; lane 2 - BGM 264; lane 3 - BGM 561; lane 4 - BGM 563; lane 5 - BGM 337; lane 6 - BGM 316; lane 7 - BGM 340; lane 8 - BGM 640; lane 9 - BGM 1723; lane 10 - BGM 1840; lane 11 - BGM 638; lane 12 - BGM 1123; lane 13 - BGM 668; lane 14 - BGM 1037; lane 15 - 1811; lane 16 - BGM 1245; lane 17 - BGM 1324; lane 18 - BGM 1345; lane 19 - BGM 1348; lane 20 - BGM 1371; lane 21 - BGM 116; lane 22 - BGM 1282) maintained in the field and present in the Cassava Active Germplasm Bank (Banco Ativo de Germoplasma - BAG - Mandioca) of Embrapa Cassava \& Fruits, Cruz das Almas, State of Bahia.

In the present study, the greatest genetic dissimilarity among cassava accessions was between BGM 668 and $1840(0.32)$, and the lowest genetically dissimilar accessions were BGM 1037 and 1324 (0.07) (Table 4). This behavior reflects the different origins of these materials.

Silva et al. (2011) evaluated the intra- and inter-specific genetic diversity of Manihot accessions using ISSR markers and observed the greatest dissimilarity $(0.69)$ between $M$. esculenta var. mandiocaba and M. dichotoma and the lowest dissimilarity (0.49) between $M$. dichotoma var. undulata and M. caerulescens. In this case, the authors observed greater dissimilarity among individuals of the same species compared to among different species of the same genus.

Zayed et al. (2013) used ISSR markers to measure the genetic distance between 4 cassava genotypes imported from Indonesia, Brazil, and Thailand ( 2 genotypes). The authors found greater dissimilarity $(0.25)$ between genotypes from Brazil and Indonesia and the lowest dissimilarity between genotypes from Thailand and Brazil.

These observations and the results of the present study clearly demonstrate the efficiency of ISSR markers for revealing genetic diversity in cassava, both among genotypes of the same species and among species of the same genus.

A dendrogram was constructed from 100 polymorphic bands, and the arithmetic complement of the Jaccard's index was used to construct the genetic similarity matrix (Figure 2). The 22 cassava accessions were separated into 7 groups according to the unweighted pairgroup method using arithmetic averages grouping method, and the cutoff was chosen according to the criteria of Mingoti (2005).

The 1st group (G1) was formed by 2 accessions, BGM 212 and BGM 1282. The 2nd group (G2) was formed by the accessions BGM 264, BGM 340, BGM 337, BGM 640, BGM 316, BGM 561, BGM 563, and BGM 1723. The 3rd group (G3) was formed only by BGM 638. The 4th group (G4) contained the accessions BGM 1123, BGM 1348, BGM 1037, BGM 1324, BGM 1345, BGM 1245, BGM 1371, and BGM 116. The 5th (G5), 6th (G6), and 7th groups (G7) were formed by accessions BGM 1811, BGM 668, and BGM 1840 , respectively. 
Fidelity and variability of cassava plants using ISSR markers

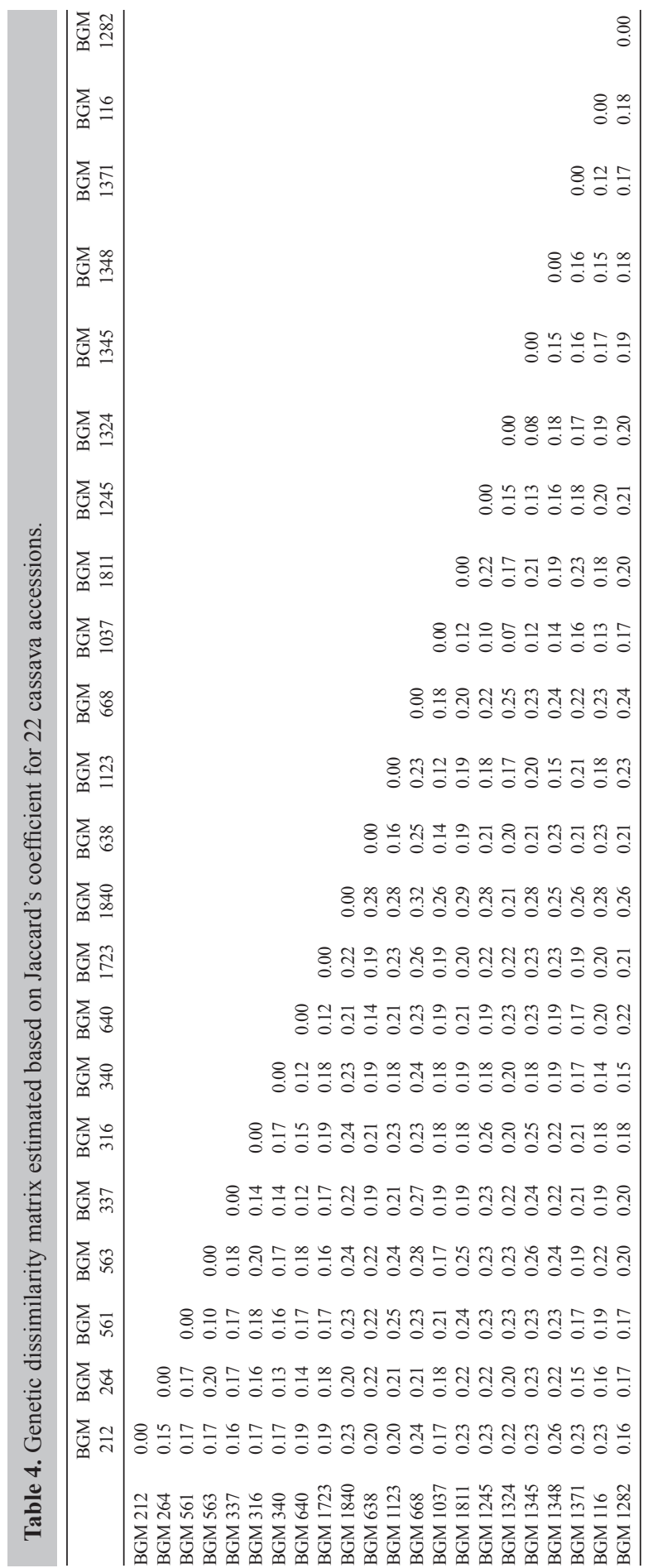




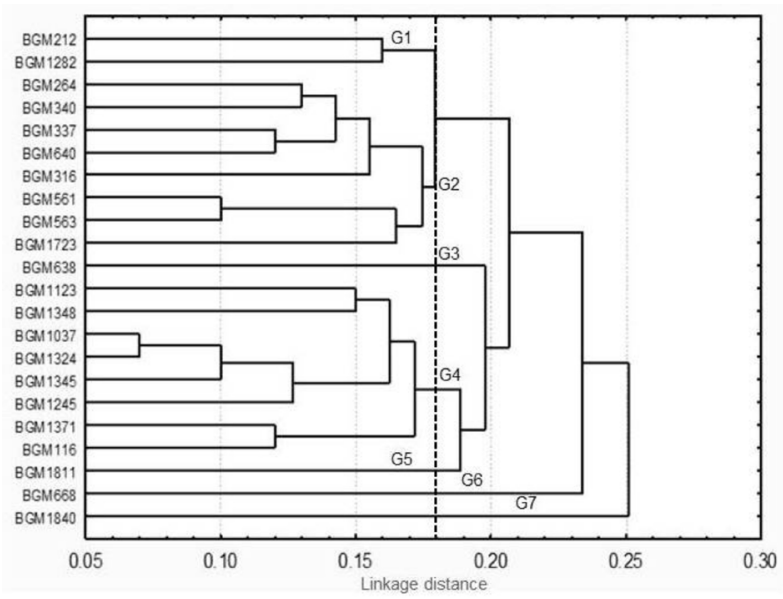

Figure 2. Dendrogram generated by unweighted pair group method using arithmetic averages using 100 polymorphic bands from 24 ISSR markers showing the genetic relationships between 22 cassava accessions found in the Cassava Active Germplasm Bank of Embrapa Cassava \& Fruit.

Among the groups formed, only the 2nd group (G2) contained accessions with similar suitability. Although they originated from different regions of Brazil, these accessions are suitable for flour production. The other groups (G1, G3, G4, G5, and G7) consisted of accessions suitable for human consumption and/or flour production, except for the 6th group (G6), which showed no relation to suitability to other accessions.

This preliminary study of genetic diversity among accessions maintained in the field revealed variability that can be used in the breeding program of this species.

\section{Genetic fidelity between accessions from the field and cultured in vitro}

For most of the electrophoretic profiles tested in our study with 24 ISSR markers, the fidelity between accessions in the field and those multiplied in vitro for 7 subcultures was assessed. Figure 3 shows the electrophoretic profiles of plants maintained in the field (c) and matched plants from 7 subcultures in vitro (i) using the ISSR 39 primer.

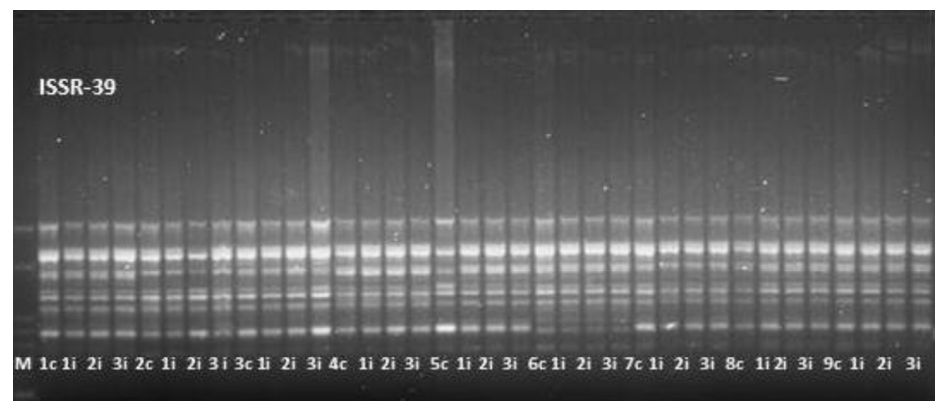

Figure 3. Electrophoretic profile on a $2.5 \%$ agarose gel of the ISSR 39 primer in plants maintained in the field (c) and matched clones derived from meristems (1i, 2i, 3i) of nine cassava accessions (1-9). Lane 1 - BGM 212; lane 2 - BGM 264; lane 3 - BGM 561; lane 4 - BGM 563; lane 5 - BGM 337; lane 6 - BGM 316; lane 7 - BGM 340; lane 8 - BGM 640; lane 9 - BGM 1723. Lane $M=1-\mathrm{kb}$ DNA ladder (Invitrogen). 


\section{DISCUSSION}

Several authors have used tissue culture to regenerate cassava plants using either organogenesis with meristem cultures (Oliveira et al., 2000) or axillary buds and nodal explants (Konan et al., 1997; Lima et al., 2002), or through somatic embryogenesis (Hankoua et al., 2005; Saelim et al., 2006). However, there have been no reports of studies examining somaclonal variation in cassava plants regenerated by one of the systems mentioned above, except for the study by Raemakers et al. (2001), who observed variations in the shape, color, and size of leaves, the presence of branches, and reduced size and vigor in transgenic plants regenerated from the culture of friable embryogenic callus in 6 of the 10 cassava genotypes tested. These observations were performed at the morphological level, with no other records using molecular markers. Molecular markers are widely used for studies of genetic similarity, divergence, variability, and molecular characterization of the cassava crop (Costa et al., 2003; Vieira et al., 2008, 2010).

Several authors have also used ISSR markers to determine the genetic fidelity of micropropagated plants. Pathak and Dhawan (2012) confirmed the clonal stability of 22 subcultures of apple rootstock Merton 793 plants regenerated from axillary buds using 15 ISSR primers. These authors observed a homogeneous amplification profile for all micropropagated plants compared with the donor plant.

Similarly, Lu et al. (2011) used 45 ISSR primers to assess genetic identity and monitor somaclonal variation of 30 banana cultivars during micropropagation using meristems as the source of explants. The authors also observed a homogeneous amplification profile in all micropropagated plants compared with their parent plants.

The results of the present study are consistent with those of previous reports describing the applicability of ISSR markers for studying the fidelity of meristem-derived plants. However, interesting observations may be made regarding the likelihood of somaclonal variation with the use of the ISSR 37 (Figure 4) and ISSR 25 (Figure 5) primers, which show examples of genetic differences between accessions multiplied in vitro and their corresponding accessions maintained in the field.

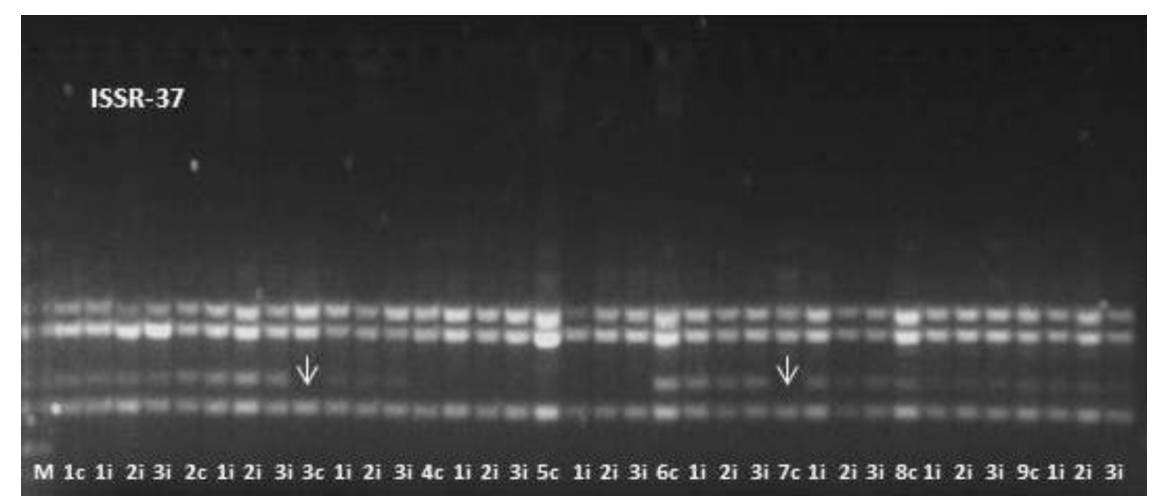

Figure 4. Electrophoretic profile on a $2.5 \%$ agarose gel of the ISSR 37 primer in plants in the field (c) and matched clones derived from meristems (1i, 2i, 3i) of nine cassava accessions. Lane 1 - BGM 212; lane 2 - BGM 264; lane 3 - BGM 561; lane 4 - BGM 563; lane 5 - BGM 337; lane 6 - BGM 316; lane 7 - BGM 340; lane 8 - BGM 640; lane 9 - BGM 1723. Lane $M=1-\mathrm{kb}$ DNA ladder (Invitrogen). White arrows indicate accessions from the field with genetic divergences compared with matched material multiplied in vitro. 


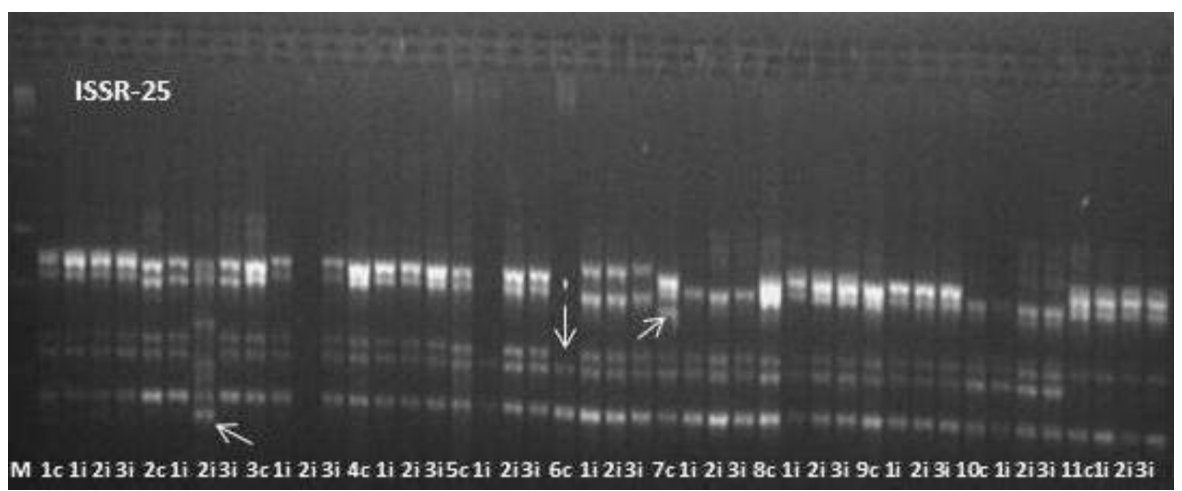

Figure 5. Electrophoretic profile on a $2.5 \%$ agarose gel of the ISSR 25 primer in plants maintained in the field (c) and matched clones derived from meristems (1i, 2i, 3i) of 11 cassava accessions. Lane 1 - BGM 212; lane 2 - BGM 264; lane 3 - BGM 561; lane 4 - BGM 563; lane 5 - BGM 337; lane 6- BGM 316; lane 7 - BGM 340; lane 8 - BGM 640; lane 9 - BGM 1723, lane 10 - BGM 1840, lane 11 - BGM 638. Lane M=1-kb DNA ladder (Invitrogen). White arrows represent genetic divergences between materials.

Figure 4 shows the difference between the accessions maintained in the field and those propagated in vitro when using the ISSR 37 primer, e.g., for the BGM 561 and BGM 340 accessions, for which the in vitro accessions exhibited a band while their matched field accessions did not. For the BGM 561 accession, this difference appeared only when the ISSR 37 primer was used. The genetic difference between the BGM 340 accession maintained in the field and its corresponding in vitro accession was evident for primers ISSR 37, 25, 90, 47, and 36 . These results indicates that there may have been a problem with the collection or that somaclonal variation was present, which may be exploited in future cassava breeding programs.

The primer that generated the largest number of genetic differences between the material from the field and the accessions multiplied in vitro was ISSR 25. Figure 5 shows that this primer revealed genetic differences between field accessions and matched subcultured representatives of the BGM 316 and BGM 340 accessions. The BGM 316 accession exhibited a missing band in the field accession compared with the accession subcultured in vitro, and the BGM 340 accession showed a missing band compared with its matched in vitro materials.

However, for the BGM 316 accession, this missing band was only observed for this specific primer, and there were insufficient replicates to demonstrate the presence of somaclonal variation or any other occurrence, such as collection error. Further studies of the BGM 430 accession are necessary to determine whether there was somaclonal variation or whether there were problems in the collection.

The cassava germplasm bank maintained in the field is always changing locations, which may lead to problems in identifying and swapping of accessions, which can affect genetic analysis at the DNA level.

Based on the results of this study, the micropropagation/subculture method adopted by the Plant Tissue Culture Laboratory of Embrapa Cassava \& Fruit clearly maintained the fidelity of accessions grown in the field and multiplied in vitro.

To better identify somaclonal variation, a greater number of in vitro replicates of the material being multiplied and the use of other techniques, such as cytogenetics, flow cytometry, sequencing, cloning, and sequence alignment of fragments, are required in addition to field tests to determine the behavior of possible somaclonal variation. 
Molecular analysis revealed the genetic uniformity among most plants cultured in vitro and matched plants maintained in the field for the assessed accessions.

The ISSR markers were efficient for determining the genetic homogeneity of cassava plants derived from meristem culture, thus demonstrating the reliability of the propagation system.

There may be somaclonal variation of the BGM 340 accession, but further studies are necessary to support this hypothesis.

\section{ACKNOWLEDGMENTS}

The authors acknowledge the Brazilian Federal Agency for Support and Evaluation of Graduate Education (Coordenação de Aperfeiçoamento de Pessoal de Nível Superior, CAPES) and the staff from the Laboratory of Tissue Culture and Molecular Biology of Embrapa Cassava \& Fruits.

\section{REFERENCES}

Adeyemo S (2009). Molecular genetic characterization of photoperiodic genes in cassava (Manihot esculenta Crantz) and attempts to manipulate their expression to promote floral induction. Doctoral thesis, Universität zu Köln, Köln.

Alves EJ, Lima MB, Santos-Serejo JA and Trindade AV (2004). Propagação. In: O cultivo da bananeira (Borges AL and Souza LS, eds.). Embrapa Mandioca e Fruticultura, Cruz das Almas, 59-86.

Bhatia A, Singh KP, Jhang T and Sharma TR (2009). Assessment of clonal fidelity of micropropagated gerbera plants by ISSR markers. Sci. Hort. 119: 208-211.

Borba RS, Garcia MS, Kovalleski A, Oliveira AC, et al. (2005). Dissimilaridade genética de linhagens de Trichogramma Westwood (Hymenoptera: Trichogrammatidae) através de marcadores moleculares ISSR. Neotrop. Entomol. 34: 565-569.

Costa MR, Cardoso HR and Ohaze MMM (2003). Similaridade genética de cultivares de mandioca (Manihot esculenta) por meio de marcadores RAPD. Cienc. Agrotec. 27: 158-164.

Cruz CD (2007). Programa Genes, Versão Windows (2003.0.0). UFV, Viçosa.

Doyle JJ and Doyle JL (1987). A rapid DNA isolation procedure for small quantities of fresh leaf tissue. Phytochem. Bull. 19: 11-15.

Fukuda WMG, Silva SO and Iglesias C (2002). Breeding cassava. Crop Breed. Appl. Biotechnol. 2: 617-638.

Fukuda WMG, Iglesias C and Silva SO (2003). Melhoramento da mandioca. Documentos 53. Embrapa Mandioca e Fruticultura, Cruz das Almas.

Gantait S and Sinniah UR (2011). Morphology, flow cytometry and molecular assessment of ex-vitro grown micropropagated anthurium in comparison with seed germinated plants. Afr. J. Biotechnol. 10: 13991-13998.

Goulão L and Oliveira CM (2001). Molecular characterisation of cultivars of apple (Malus x domestica Borkh.) using microsatellite (SSR and ISSR) markers. Euphytica 122: 81-89.

Grattapaglia D and Machado MA (1998). Micropropagação. In: Cultura de tecidos e transformação genética de plantas (Torres AC, Caldas LS and Buso JA, eds.). Embrapa-SPI, Embrapa-CNPH, Brasília, 183-260.

Hankoua BB, Ng SYC, Fawole I, Puonti-Kaerlas J, et al. (2005). Regeneration of a wide range of African cassava genotypes via shoot organogenesis from cotyledons of maturing somatic embryos and conformity of the fieldestablished regenerants. Plant Cell. Tiss. Org. Cult. 82: 221-231.

Konan NK, Schiipke C, Cárcamo R, Beachy RN, et al. (1997). An efficient mass propagation system for cassava (Manihot esculenta Crantz) based on nodal explants and axillary bud-derived meristems. Plant Cell Rep. 16: 444-449.

Lima GPP, Barsalobres C, Piza IMT and Cereda MP (2002). Efeito do BAP e ANA e atividade da peroxidase em mandioca (Manihot esculenta CRANTZ cv Mcol 22) cultivada in vitro. Rev. Bras. Agroc. 8: 107-110.

Lu Y, Zhang X, Pu J, Qi Y, et al. (2011). Molecular assessment of genetic identity and genetic stability in banana cultivars (Musa spp.) from China using ISSR markers. Aust. J. Crop Sci. 5: 25-31.

Mingoti SA (2005). Análise de dados através de métodos de estatística multivariada: uma abordagem aplicada. $1^{\mathrm{a}}$ ed. UFMG, Belo Horizonte.

Moro AL (2009). Obtenção de massa de mandioca com adição de maltodextrina de amido de milho waxy. Master's thesis, Universidade Estadual Paulista Júlio de Mesquita Filho, Botucatu.

Nookaraju A and Agrawal DC (2012). Genetic homogeneity of in vitro raised plants of grapevine cv. Crimson Seedless

Genetics and Molecular Research 14 (3): 7759-7770 (2015)

CFUNPEC-RP www.funpecrp.com.br 
revealed by ISSR and microsatellite markers. S. Afr. J. Bot. 78: 302-306.

Oliveira RP, Gomes TS and Vilarinhos AD (2000). Avaliação de um sistema de micropropagação massal de variedades de mandioca. Pesq. Agrop. Bras. 35: 2329-2334.

Pathak H and Dhawan V (2012). ISSR assay for ascertaining genetic fidelity of micropropagated plants of apple rootstock Merton 793. In vitro Cell. Dev. Biol. - Plant. 48: 137-143.

Raemakers K, Schreuder M, Pereira I, Munyikwa T, et al. (2001). Progress made in FEC transformation of cassava. Euphytica 120: 15-24.

Ribeiro AP (2012). Micropropagação, avaliação da variação somaclonal e detecção de vírus em videira. Master's thesis, Universidade Federal de Lavras, Lavras.

Saelim L, Phansiri S, Netrphan S and Suksangpanomrung M (2006). Optimization of in vitro cyclic somatic embryogenesis and regeneration of the Asian cultivars of cassava (Manihot esculenta Crantz) for genetic manipulation system. Global J. Biotechnol. Biochem. 1: 7-15.

Silva KVP, Alves AAC, Martins MIG, Melo CAF, et al. (2011). Variabilidade genética entre acessos do gênero Manihot por meio de marcadores moleculares ISSR. Pesq. Agrop. Bras. 46: 1082-1088.

Silva MN, Cereda MP and Fiorini RA (2002). Multiplicação rápida de mandioca. In: Agricultura: tuberosas amiláceas Latino Americanas (Cereda MP, coord.). Fundação Cargill, São Paulo, 187-197.

Souza AS, Junghans TG, Souza FVD, Santos-Serejo JA, et al. (2009). Micropropagação da mandioca. In: Aspectos práticos da micropropagação de plantas (Junghans TG and Souza AS, eds.). Embrapa Mandioca e Fruticultura Tropical, Cruz das Almas, 323-349.

Statistica (2002). STATISTICA for Windows v. 6.0: Computer Program Manual. Editora StatSoft Inc., Tulsa.

Venkatachalam L, Sreedhar RV and Bhagyalakshmi N (2007). Genetic analyses of micropropagated and regenerated plantlets of banana as assessed by RAPD and ISSR markers. In vitro Cell. Dev. Biol. - Plant 43: 267-274.

Vieira EA, Fialho JF, Faleiro FG, Bellon G, et al. (2008). Divergência genética entre acessos açucarados e não açucarados de mandioca. Pesq. Agrop. Bras. 43: 1707-1715.

Vieira EA, Fialho JF, Faleiro FG, Bellon G, et al. (2010). Caracterização molecular e variabilidade genética de acessos elite de mandioca para fins industriais. Cienc. Rural 40: 2467-2471.

Zayed EM, Shams AS and Kamel AS (2013). Genetic diversity in introduced cassava using inter simple sequence repeat markers (ISSRs). Geneconserve 12: 23-33. 